\title{
Structural Comparisons of Cell Organelles and Nuclei in Rat Hepatocytes with Three Different Fixation Techniques
}

\author{
MASAO HAMASAKI, KENTARO SAWADA, HITOSHI MATSUO, TOSHINORI MAEHARA \\ AND HIDEO ISHIBASHI \\ Department of Anatomy, Kurume University School of Medicine, \\ Kurume 830, Japan
}

Received for publication January 14, 1997

\begin{abstract}
Summary: The morphological properties of cell organelles and nuclei in rat hepatocytes were compared, when the hepatocytes were either chemically fixed in glutaraldehyde and osmium (GA-Os), chemically fixed only in osmium (Os-2h) or physically fixed with a microwave-irradiated osmium (Mw-Os) fixative for a short duration. Judging from the fine structure, the mitochondria and rER were best preserved after physical fixation; because of the smooth surfaces and regular open contours, but both organelles shrank in the two chemical fixatives. The Golgi complexes and peroxisomes of the hepatocytes were not markedly changed by any of the fixative procedures. However the lysosomes and sER were changed to some extent after physical fixation. In the nucleus, the two kinds of chromatins and the nucleolus were best preserved with physical fixation. In conclusion, physical fixation is a very simple and fast procedure that is convenient for routine electron microscopy if some attention is paid to the morphological changes.
\end{abstract}

Key words chemical or physical fixation, microwave-irradiation, fine structure, hepatocyte, cell organelles, nucleus

\section{Introduction}

Cryopreservation by rapid freezing allows living cells to be studied in their physiological state by high-resolution electron microscopy (Dalen et al. 1992; Hanyu et al. 1992). For this purpose very fast freezing is imperative, both for stopping physiological processes almost instantly and for preserving ultrastructural profiles without cryoartifacts, such as ice-crystals. With the freezefixation technique, antigenicity of the cellular molecules is maintained and cellular structures are preserved better than with chemical fixation (Login et al. 1995). On the other hand, fast microwave (Mw) fixation has also been applied in many tissues (Wild et al. 1989; Login et al. 1990; Mizuhira, 1990; Heumann, 1992) to obtain cellular preservation as good as with the freezefixation technique. Comparing Mw-fixation with freeze-fixation, the Mw-fixation is simpler, and is more reproducible. Login et al. (1990) have shown

Correspondence to: Masao Hamasaki, Department of Anatomy, Kurume University School of Medicine, 67 Asahi-machi, Kurume 830, Japan. 
that Mw-osmium fixation of rat skeletal muscle and hepatic cells for $6 \mathrm{~s}$ results in especially good morphological characteristics for mitochondria, myofibrils, endoplasmic reticulum and peroxisomes. The ultimate aim of morphological enquiries into cell architecture is a description of the in-vivo state and its physiological correlates. Chemical fixation profoundly alters the in-vivo state, and quick-frozen cells develope cryoartifacts. The purpose of this study is to compare the morphological characteristics of hepatic cell organelles and nuclei, ultrastructurally, after three different fixation procedures, chemical fixation with glutaraldehyde and osmium, chemical fixation with a single immersion in osmium, and physical fixation with microwave-irradiated osmium.

\section{Materials and Methods}

Adult rats were anesthetized with Ketalar, the thoracic aorta was cannulated and the circulary blood was removed with a saline infusion. For transmission electron microscopy, blocks of hepatic tissue were prepared by physical fixation with microwaveirradiated osmium (Mw-Os) by chemical fixation with glutaraldehyde and osmium (GA-Os) or by chemical fixation with only osmium (Os-2h).

For physical fixation, fresh liver was cut into small blocks 1 to $3 \mathrm{~mm}$ in length after removing the blood from the rat. Five blocks were placed in $7.5 \mathrm{ml}$ of $2 \%$ $\mathrm{OsO}_{4}$ in $0.1 \mathrm{M}$ phosphate buffer (Os) in a glass vial. These vials were then immersed in a glass tray filled with cold water $\left(5^{\circ} \mathrm{C}, 300 \mathrm{ml}\right)$. The tray was placed in a MW (Nishin Co LTD, 500W) equipped with a turntable. For subcellular structural preservation, the optimum temperature and time of the $\mathrm{Mw}$ irradiation is reported to be different for different tissues (Gokhale and Khan, 1992; Heumann, 1992). With respect to time, irradiation of some tissues for 7 to $9 \mathrm{~s}$ gave results similar to irradiation for $90 \mathrm{~s}$. Five to $10 \mathrm{~s}$ has been recommended as an optimal time for irradiation during Mw fixation (Login and Dvorak, 1985; Wild et al. 1989; Argall and Armati, 1990). Following this recommendation, the blocks for the Mw-Os samples were irradiated for 5 or $10 \mathrm{~s}$ with an increase in temperature up to $4{ }^{\circ} \mathrm{C}$. As a control for the Mw-Os samples, blocks immersed in $2 \%$ buffered $\mathrm{OsO}_{4}$ solution for only 10 $\mathrm{s}$ were designated as Os-10s samples .

The remaining blocks were chemically immersed in $2.5 \%$ glutaraldehyde $2 \%$ formaldehyde in $0.1 \mathrm{M}$ phosphate buffer for 2 hs at room temperature and then post-fixed with $2 \% \mathrm{OsO}_{4}$ buffered solution for 2 hs at $4{ }^{\circ} \mathrm{C}$ (designated as GA-Os samples) or immersed in only $2 \%$ $\mathrm{OsO}_{4}$ buffered solution for 2 hs at $4{ }^{\circ} \mathrm{C}$ (Os-2h samples).

Thereafter, the four different types of fixed blocks were dehydrated in a serial series of acetone, and embedded in Epon 812. Semithin sections (1.5 um in thickness) were cut on a Reichert microtome, mounted on a glass slide, stained with toluidine blue, and examined by light microscopy. Then ultrathin sections (ca $90 \mathrm{~nm}$ in thickness) were obtained using diamond knives, doublestained with uranyl acetate and lead citrate, and observed with TEM (JEM2000EX, Jeol LTD). 

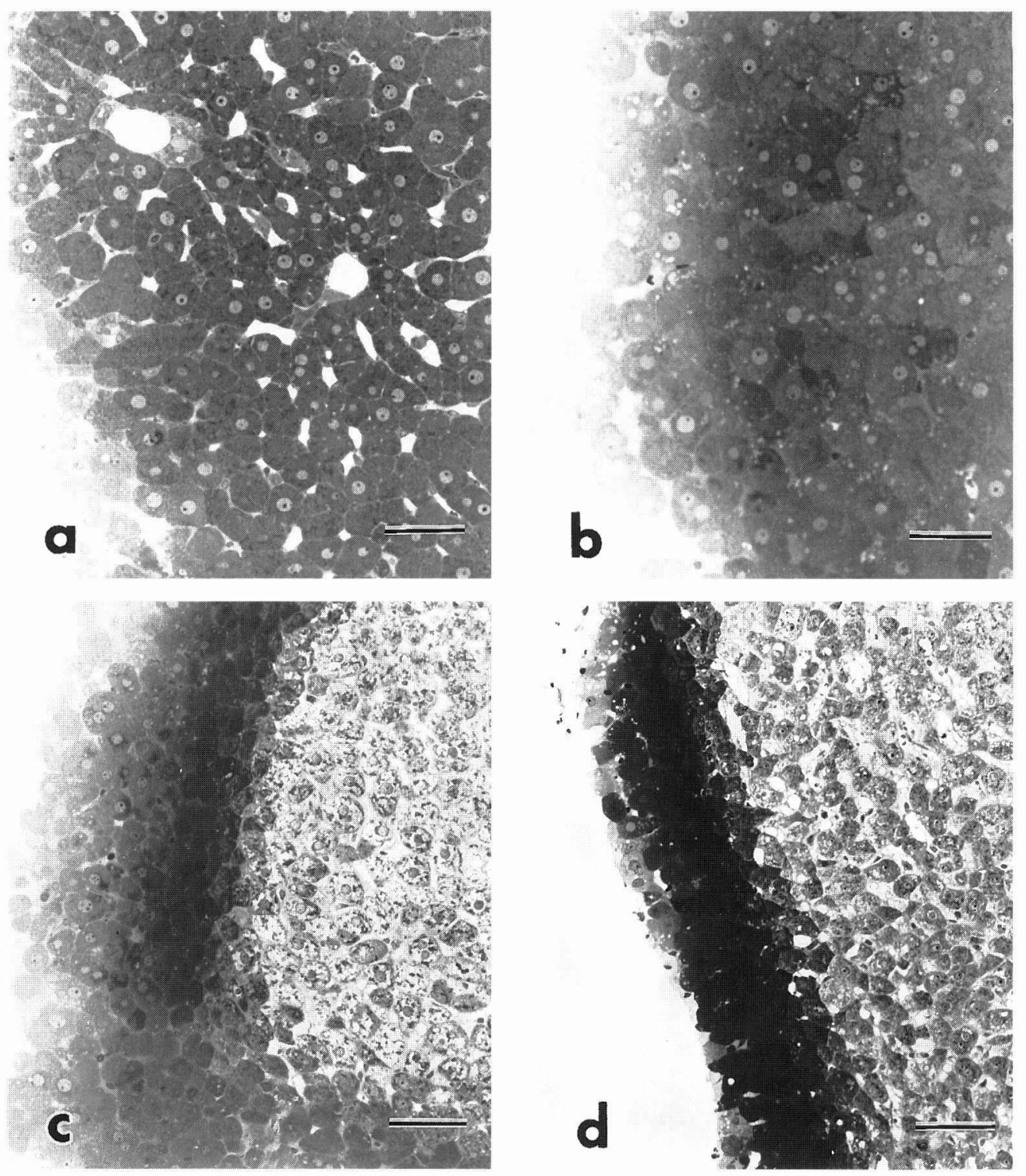

Fig. 1. Light micrographs of toluidine blue-stained $1.5 \mathrm{um}$ Epon sections of rat liver fixed by a) conventional double fixation (GA-Os), each for $2 \mathrm{hs}$; b) single fixation (Os-2h) for $2 \mathrm{hs}$; c) single fixation (Os-10s) for $10 \mathrm{~s}$; and d) microwave-osmium fixation (Mw-Os) for $5 \mathrm{~s}$. Most of the rat hepatocytes were uniformly fixed in the double chemical samples, while only ten cell layers were fixed with the Os-10s and Mw-Os samples. a) $\sim$ d) bar $=50 \mathrm{um}$ 

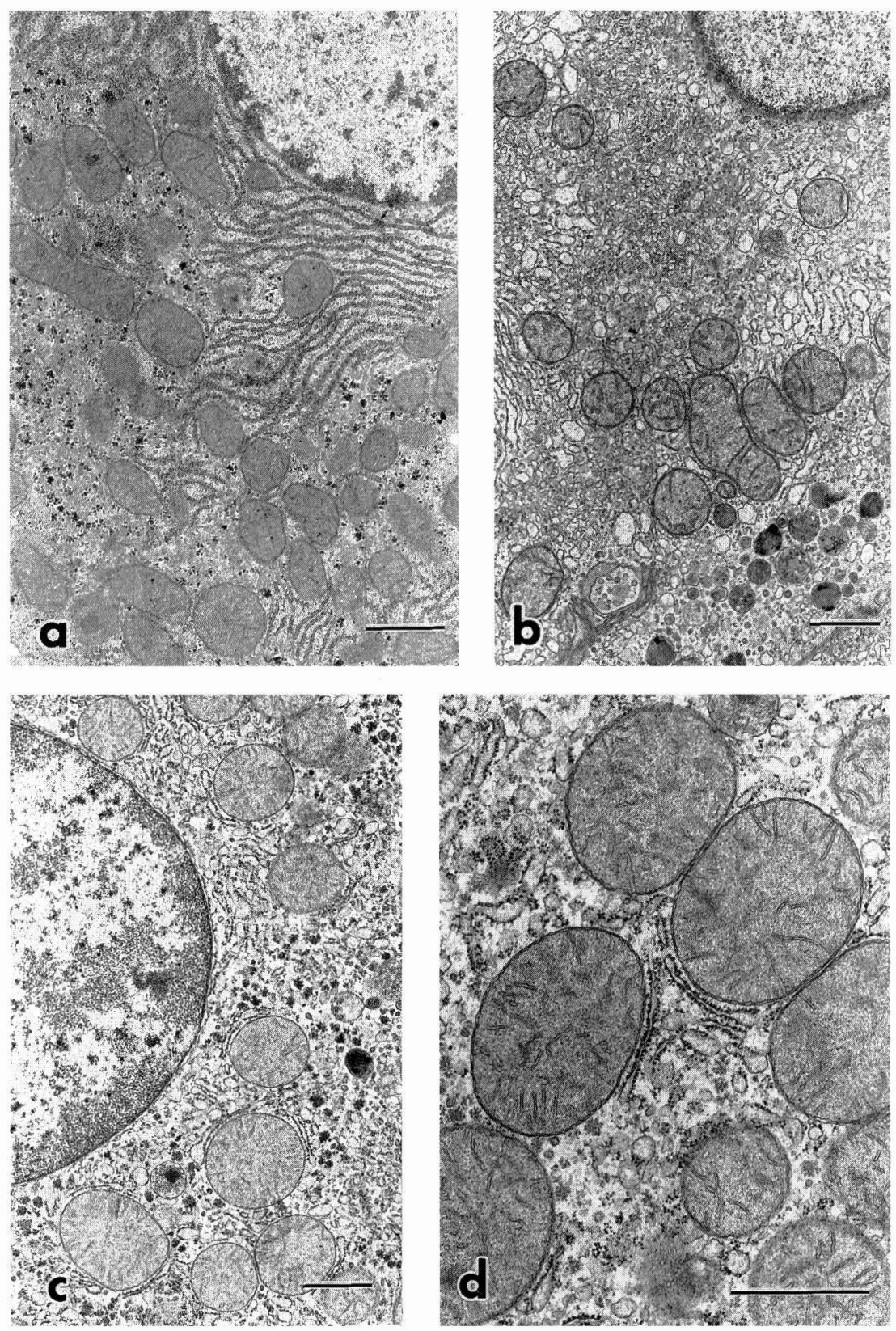

Fig. 2. Electron micrographs of rat hepatocytes fixed by a) conventional (GA-Os) fixation; b) single (Os-2h) fixation; and c) and d) Mw-osmium (MwOs) fixation. The lumina of the endoplasmic reticulum are closed in the GA-Os samples, narrowed or dilated at some points in the Os-2h samples and usually opened in the Mw-Os samples. The mitochondria are small and more or less angular in the GA-Os and Os-2h samples, while they are large, smooth and rounded in contour in the Mw-Os samples. a) d) bar=1 um 

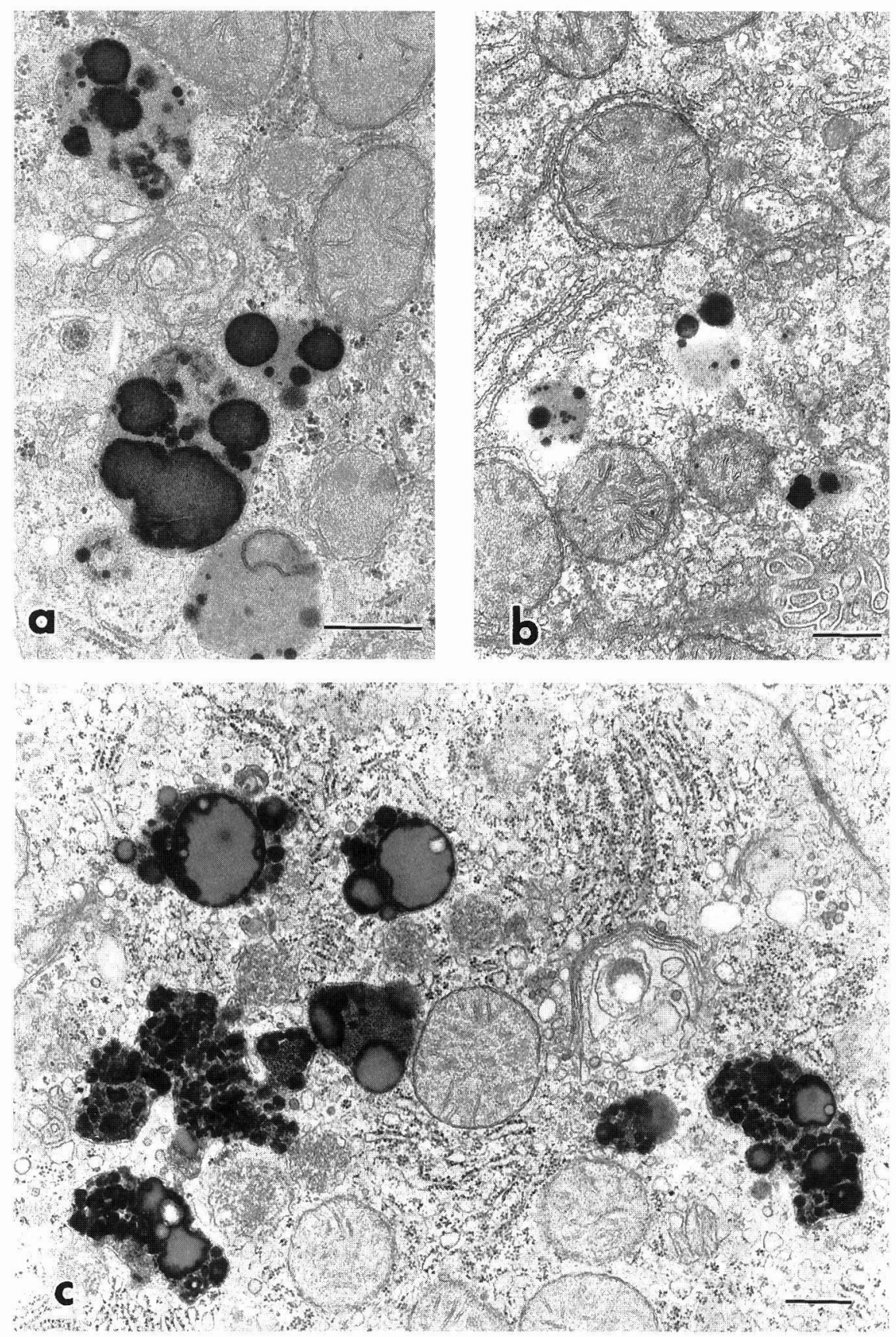

Fig. 3. High-magnification electron micrographs of rat hepatocytes. The sER are branched in the GA-Os samples (a), more or less destroyed in the Os-2h samples (b) and vesiculated in the Mw-Os samples (c). The lysosomes are of the primary or secondary types with limiting membranes in the GA-Os and Os-2h samples, and of the lipofuscin type in the Mw-Os samples. a) c) bar=0.5 um 

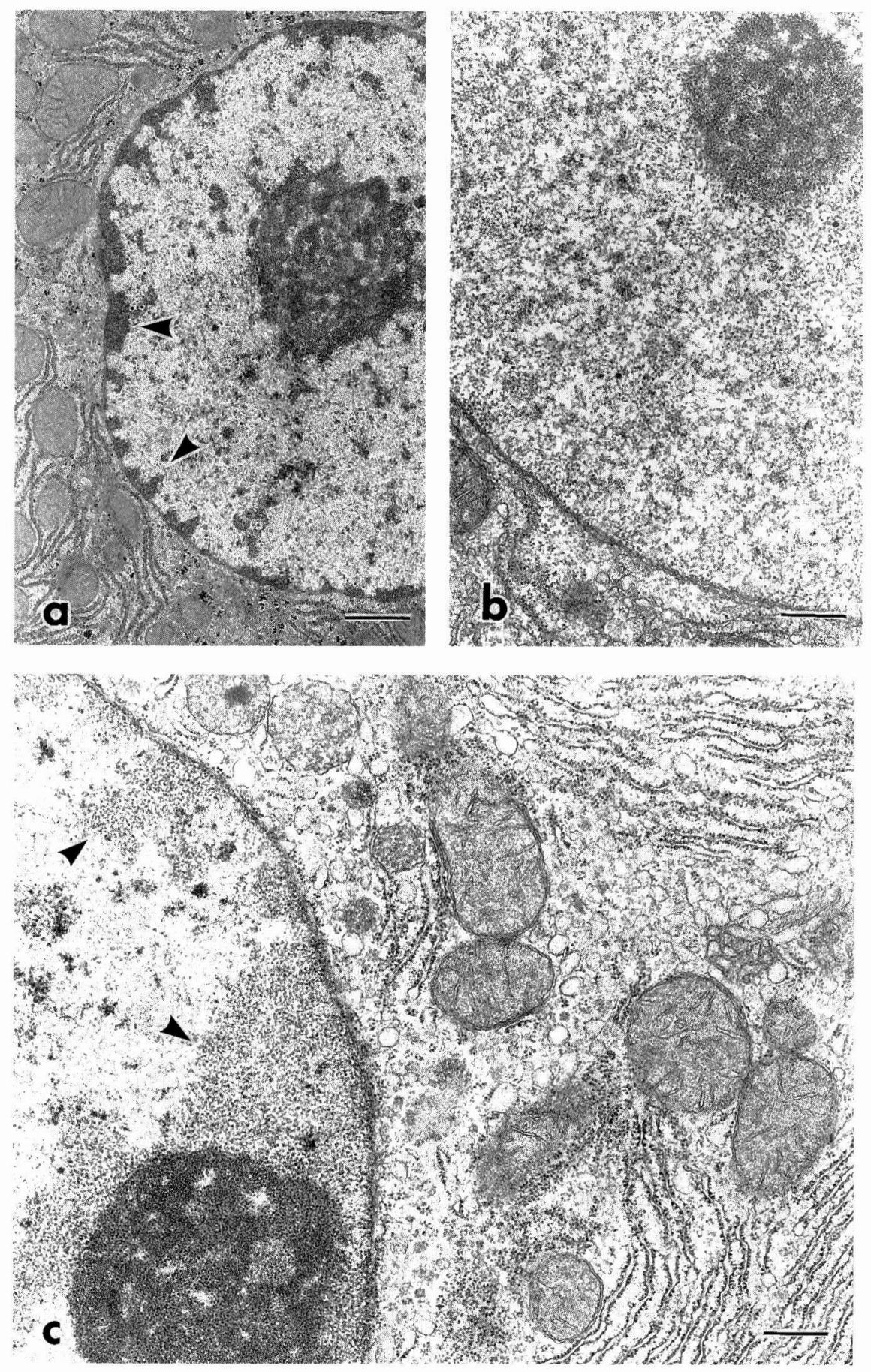

Fig. 4. Hetero-nuclear chromatins (arrowheads) and the nucleolus were discernable in the hepatic cells of the GA-Os (a) and Mw-Os samples (c), but not in the Os-2h samples (b). a) bar=1 um, b) and c) bar=0.5 um 


\section{Results}

Figs 1a-d are semithin light microscopic pictures of rat hepatic cells which were obtained by the four different fixation methods. With the conventional chemical fixation (GA-Os samples), 2 to 3 cell layers from the cut end of the liver blocks were lightly stained in Toluidine blue and compared with the hepatocytes located more deeply than 3 cell layers (Fig. 1a). This technique allows the cells located beyond 10 cell layers to be fully and uniformly fixed. In the Os-2h samples, the osmium had dispersed into almost all cells (Fig. 1b). In contrast, the osmium in the Os-10s samples was apparently dispersed in 8 to 10 cell layers, but not to the more deeply located cells (Fig. 1c). In the Mw-Os samples, the osmium physically reached up to approximately
10 cell layers but never fully fixed the more deeply located cells (Fig. 1d). In addition, the hepatic sinusoids were normally opened in the GA-Os samples, but were often closed in the other samples. When the samples were observed by TEM, the fixatives reached only 1 to 2 cell layers in the Os-10s samples as judged by the preservation of the cell organelles, while they reached 4 to 6 cell layers in spite of the short duration (5 s) with the Mw-Os samples. Typical EM pictures of the cell organelles in the 4 to 6 cell layers were obtained with the two chemical samples. Thus, except for the Os-10s samples, the cell organelles and nuclei of the hepatocytes in 4 to 6 cell layers were ultrastructurally compared for the two chemical fixations, GA-Os and Os-2h, and the one physical fixation, $\mathrm{Mw}-\mathrm{Os}$, respectively. Of all the cell organelles, the mitochondria and rough endoplasmic

TABLE 1.

Morphological characteristics of cell organelles and nuclei in rat hepatic cells obtained by three different fixation procedures

\begin{tabular}{|c|c|c|c|}
\hline & GA-Os & Os-2h & Mw-Os \\
\hline $\begin{array}{l}\text { cell organelles } \\
\text { mitochondria } \\
\text { and outer membrane } \\
\text { rER and lumen } \\
\text { golgi complex } \\
\text { sER and lumen } \\
\text { lysosome }\end{array}$ & $\begin{array}{l}\text { angular contour } \\
\text { fine irregular } \\
\text { bended and closed } \\
\text { normal } \\
\text { branching tubules } \\
\text { 1st and 2nd lysosomes }\end{array}$ & $\begin{array}{l}\text { ovoidal contour } \\
\text { fine irregular } \\
\text { partial dilatation } \\
\text { normal } \\
\text { partial dilatation } \\
\text { 1st and 2nd lysosomes }\end{array}$ & $\begin{array}{l}\text { round contour } \\
\text { smooth } \\
\text { short, regularly opened } \\
\text { normal } \\
\text { vesiculation } \\
\text { lipofuscin }\end{array}$ \\
\hline $\begin{array}{l}\text { nucleus } \\
\text { nucleolus (stain\#) } \\
\text { dif.\# of two chromatins }\end{array}$ & $\begin{array}{l}\text { intermediately } \\
\text { possible }\end{array}$ & $\begin{array}{l}\text { weakly } \\
\text { impossible }\end{array}$ & $\begin{array}{l}\text { strongly } \\
\text { possible }\end{array}$ \\
\hline
\end{tabular}

Abbreviations: GA-Os=glutaraldehyde and osmium fixative for 2 hours. Os- $2 \mathrm{~h}=\mathrm{osmium}$ fixative for 2 hours. Mw-Os=microwave-irradiated in osmium fixative for 5 seconds. stain\#=staining strength of the nucleolus dif.\#=differentiation between eu- and hetero-chromatins 
reticuli ( $\mathrm{rER}$ ) were the most different in morphology among the three samples (Figs 2a-d). Namely, the mitochondria were small and had a more or less angular contour in the two chemical samples, while they were large and had a smooth rounded contour in the physical sample. The latter were smoother and had sharper limiting membranes, such as in the mitochondrial crista and its outer membrane, than the mitochondria of hepatocytes in the other samples. Further, the mitochondrial substrates were very electron dense in the Os- $2 \mathrm{~h}$ samples, intermediate in the GA-Os samples and electron lucent in the MwOs samples. The rER was arranged in a chordal fashion with some bending points in both chemical samples, but was arranged as short tubules in the physical sample. The lumina of the rER were closed in the GA-Os samples, mostly narrowed and partially dilated in the Os-2h samples but were usually opened in the Mw-Os samples (Figs 2ad). The Golgi complexes and peroxisomes of the hepatocytes were not noticeably different for the three different fixation procedures. On the other hand, the smooth endoplasmic reticula (SER) were anastomosed or branched in the GA-Os samples, while they were partially dilated or destroyed in the Os-2h samples and formed small vesicles in the Mw-Os samples. The primary and secondary lysosomes were present in both the GA-Os and Os-2h samples, but were sometimes transformed into lipofuscins in the $\mathrm{Mw}$-Os samples (Figs 3a-c). In addition, the hetero-chromatin and nucleoli were well preserved in the individual nuclei of hepatocytes in the GA-Os and the Mw-Os samples, but were impossible to find or less dense in the Os-2h samples (Fig. 4). Table 1 summarizes the structural changes of these cell organelles and the nuclei of the hepatic cells obtained by the three different fixation methods.

\section{Discussion}

Liver blocks were chemically fixed in GA-Os and Os-2h and physically fixed in Mw-Os. Due to the very slow rate of fixative penetration $(0.6$ to $0.8 \mathrm{~mm} / \mathrm{hr})$ into soft tissues, the tissue specimens must be as small as ca $1 \mathrm{~mm}^{3}$ for conventional chemical fixation (Hayat, 1981; Login et al. 1990). In fact, it has been determined with LM and EM that the GA and Os could penetrate from the cut end of the blocks to deeply located cells (more than 10 cell layers) and these techniques allowed widely distributed cells to be preserved with a high reproducibility. The Os-2h fixation was previously used to fix the limiting membranes of the cells, but was not now used due to the superiority of the GA-Os fixation. Also the Os-2h samples displayed hepatic sinusoids that were severely destroyed by the immersion in osmium. Thus, GA-Os fixation is the preferred chemical fixation technique for routine electron microscopic (EM) studies. Nevertheless, chemical fixation for EM studies is often complicated by chemical artifacts, but these artifacts were not described in detail (Moreira et al. 1996).

As for the rapid cryosubstitution methods (Plattner and Bachmann, 1982; Hanyu et al. 1992), the microwave-irradiated fast fixation has recently resulted 
in excellent EM pictures which are very similar to native cells. In comparing physical fixation by Mw-GA and Mw-Os (Login et al. 1990), the Mw-Os fixation was said to provide the preferable EM pictures. Thus, we have also attempted to fix liver blocks with the Mw-Os fixative. When the liver blocks were physically fixed by irradiation from the microwave for $5 \mathrm{~s}$, osmium could penetrate up to 4 to 10 cell layers $(0.2$ to $0.4 \mathrm{~mm}$ ) from the cut end of the blocks. In contrast, when the Os-10s samples were studied by EM, the osmium had penetrated only into 1 to 2 cell layers. Furthermore, the effects of microwave energy on the cell organelles have not been reported. Microwave energy decreases exponentially with the depth from the cut end of the blocks (Login and Dvorak, 1988). This tendency was also observed morphologically in the present study. At 1 to 2 cell layers the cell membranes of the hepatocytes were partially broken in the Mw-Os samples. At 4 to 6 cell layers the cell organelles and their limiting membranes were fairly well preserved. However, the Os could not fully penetrate into the hepatic cells which were located more deeply than 10 cell layers, and as a result the cell organelles and their limiting membranes in these layers were almost completely destroyed.

When the GA-Os, Os-2h and Mw-Os fixatives were compared, the nuclei and cell organelles 4 to 6 cell layers deep were preserved differently. Two types of chromatin; hetero- and eu-chromatin, were discerned in the GA-Os and Mw-Os samples, but not in the Os-2h samples. Functionally, the $\mathrm{Mw}$ irradiation with magnetic waves of $2450 \mathrm{MHz}$ rotates dipolar molecules such as water and protein and transfers ionic substances such as GA and Os in and out of the nucleoplasm and cytoplasm of the hepatic cells (Login et al. 1986; Wild et al. 1989; Gokhale and Khan, 1992). This indicates that after $\mathrm{Mw}$ irradiation the Os instantaneously penetrates not only into the cytoplasm but also into the nucleoplasm of the hepatocytes up to 10 cell layers deep. Among the cell organelles in the cytoplasm, the most attractive, morphological changes occurred in the mitochondria. The mitochondria were small, more or less angular in contour with irregular outer membranes in the GA-Os and Os-2h samples, while they had a large and rounded contour with smooth outer membranes in the Mw-Os samples. The latter mitochondria were physically fixed very rapidly by $\mathrm{Mw}$ irradiation in an osmium buffered solution, and they did not shrink during the subsequent dehydration and embedding procedures. Similarly, the stereological analysis showed that tissue blocks fixed by $\mathrm{Mw}$ did not induce the organelles such as liver mitochondria and salivary gland granules to shrink or swell (Login and Dvorak, 1985). In contrast, the mitochondria fixed chemically probably shrank because of their small sizes and angular contours with irregular membranes. As a result, the structural integrity of the mitochondria seems to be maintained only with the physical fixation, but is rarely observed with freeze-substitution methods (Dalen et al. 1992). The rER with regularly opened lumina were smooth and short in $\mathrm{Mw}$ Os, while they were somewhat reflected and elongated with narrowed or closed 
lumina in GA-Os and Os-2h. The former also indicates that the structural integrity of the rER is maintained because of the regularity of the lumina. The Golgi complexes and peroxisomes were not structurally different among the three samples. In contrast, the SER was sometimes vesiculated or missing to some extent and the lysosomes also changed into lipofuscin in the Mw-Os samples, which is a disadvantage. These morphological changes were not observed with GA-Os and Os-2h. On the other hand, Wild et al. (1989) have reported that the most striking feature was the preservation of the sER and Golgi complexes in hepatocytes after Mw-irradiation in GA buffered solution. It remains unclear why these structural differences would occur between two diverse fixatives, GA and Os. The osmium, non-coagulant fixative, stabilizes lipids and lipoproteins and imparts electron density to tissue with which it reacts (Login et al. 1995). Nevertheless, the sER was vesiculated and lipofuscins were formed with Mw-Os but not with Os-2h. The sER is related to the formation of lipids, and the lipofuscin is another type of lysosome containing lipid droplets. The strong oxidation by the osmium may be physically facilitated through the energy of the Mw irradiation for a very short duration and as a result, the cell organelles would be affected according to their lipid metabolism. In the Os-2h samples, each tissue was mildly treated at $4{ }^{\circ} \mathrm{C}$ for $2 \mathrm{hs}$. Mw fixation procedures have frequently been used in recent studies (Somosy et al. 1991; Gokhale and khan, 1992; Heumann, 1992; Login et al. 1995), and have resulted in excellent structural preservation of tissues and in immunolocalization of many enzymes. However, it is natural to describe that the cell organelles, especially the mitochondria, were structurally well preserved; but attention must also be focussed on the SER and lysosomes of the rat hepatocytes after Mw irradiation in the osmium buffered solution.

In conclusion, the cell organelles of rat hepatocytes varied in the three fixatives. GA-Os fixation is recommended to observe the sER and lysosomes, while Mw-Os fixation is preferable to study the mitochondria and rER of rat hepatocytes.

Acknowledgments: The authors would like to thank Prof. Tetsuo Inokuchi for his critical advice and encouragement during the course of this study.

\section{References}

Argall K, and Armati P. Use of microwave fixation in the preparation of cell cultures for observation with the scanning electron microscope. J Elec Microsc Tech 1990; 16: 347-350.

Dalen H, Scheie P, Nassar R, High T, Scherer $B$ et al. Cryopreservation evaluated with mitochondrial and $\mathrm{Z}$ line ultrastructure in striated muscle. J Microsc 1992; 165:239254.

Gokhale JA, and Khan SR. Structure of rat kidneys following microwave accelerated fixation. Scanning Microsc 1992; 6:511-519.

Hanyu Y, Ichikawa M, and Matsumoto G. An improved cryofixation method: cryoquenching of small tissue blocks during microwave irradiation. J Microsc 1992; 165:255-271.

Hayat MA. Factors affecting the quality of fixation. In: Fixation for electron microscopy. ed.Hayat MA, Academic Press, New York, 
pp11, 1981.

Heumann HG. Microwave-stimulated glutaraldehyde and osmium tetroxide fixation of plant tissue: ultrastructural preservation in seconds. Histochemistry 1992; 97:341347.

Login GR, and Dvorak AM. Microwave energy fixation for electron microscopy. Am J Pathol 1985; 120:230-243.

Login GR, and Dvorak AM. Microwave fixation provides excellent preservation of tissue, cells and antigens for light and electron microscopy. Histochem J 1988; 20:373-387.

Login GR, Dwyer BK, and Dvorak AM. Rapid primary microwave-osmium fixation. 1. Preservation of structure for electron microscopy in seconds. J Histochem Cytochem 1990; 38:755-762.

Login GR, Ku TC, and Dvorak AM. Rapid primary microwave-aldehyde and microwaveosmium fixation: Improved detection of rat parotid acinar cell secretory granule $\alpha$ amylase using a post-embedding immunogold ultrastructural morphometric analysis. J Histochem Cytochem 1995; 43:515-523.
Login GR, Stavinoha WB, and Dvorak AM. Ultrafast microwave energy fixation for electron microscopy. J Histochem Cytochem 1986; 34:381-387.

Mizuhira V. New fixation method by the aid of microwave energy irradiation. -fixation method and its theoretical background- J Elec Micro 1990; 25:44-57.

Moreira JE, Reese TS, and Kachar B. Freezesubstitution as a preparative technique for immunoelectronmicroscopy: Evaluation by atomic force microscopy. Microsc Res Tech 1996; 33:251-261.

Plattner H, and Bachmann L. Cryofixation: A tool in biological ultrastructural research. Intern Res Cytol 1982; 79:237-304.

Somosy Z, Thuroczy G, Kubasova T, Kovacs J, and Szabo LD. Effect of modulated and continuous microwave irradiation on the morphology and cell surface negative charge of 3T3 fibroblasts. Scanning Microscopy 1991; 5:1145-1155.

Wild P, Krahenbuhl M, and Schraner EM. Potency of microwave irradiation during fixation for electron microscopy. Histochemistry 1989; 91:213-220. 